\title{
Bauhaus in the Archive
}

\section{Christina Pech}

Institutions collecting and exhibiting architecture and design profoundly influence how materials and subjects are selected, safeguarded, and, subsequently, communicated to larger audiences. When ArkDes, the Swedish centre for architecture and design, noticed the Bauhaus centennial, it seemed appropriate to highlight the institution's collection and its role; what can the archives kept at ArkDes tell us about the Bauhaus' influence on design and architecture in Sweden?

This text builds on a series of three public talks arranged during fall 2019 - "Bauhaus in the Archive"1 - and engaged with urban planning, interior design, and the realm of ideas. In keeping with the ambition to explore the collections, material from the repositories of ArkDes was made available on every occasion - original drawings, sketches, photographs, documents, correspondence, books.

The first conversation with the city architect of Kristianstad, Roger Jönsson², revolved around architect and planner Fred Forbat (Alfréd Fischl, 1897-1972), who worked for Walter Gropius at the Bauhaus and later became an influential urban planner in Sweden. In the second talk, design historian Kerstin Wickman ${ }^{3}$ discussed her archival findings and travels to the Bauhaus school with ArkDes' design specialist Jonas Olsson. Finally, the Swedish functionalist manifesto Acceptera from 1931 was put in context by three scholars. Atli Magnus Seelow ${ }^{4}$, architect and architecture historian, Helena Kåberg ${ }^{5}$, cu- rator at Nationalmuseum, and philosopher Sven-Olov Wallenstein ${ }^{6}$ have previously researched the book and joined a conversation that traced its roots to the continent spurred by the recent translation to German (Seelow, $2018^{7}$ ).

\section{Canon and Archive}

The relationship between a canon, commonly considered established accounts of past events, and an archive, the supposedly indiscriminate accumulation of material remains, is undeniably intriguing. ${ }^{8}$ It is by any means a contested realm where different interests and methods will inevitably privilege some narratives and silence others.

The collections of ArkDes contain archives of some 600 architects that practiced in Sweden. Embedded in less illustrious piles of protocols, bills, and itineraries, is evidence of Swedish architects' interests in

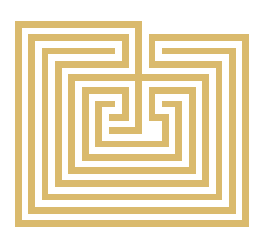




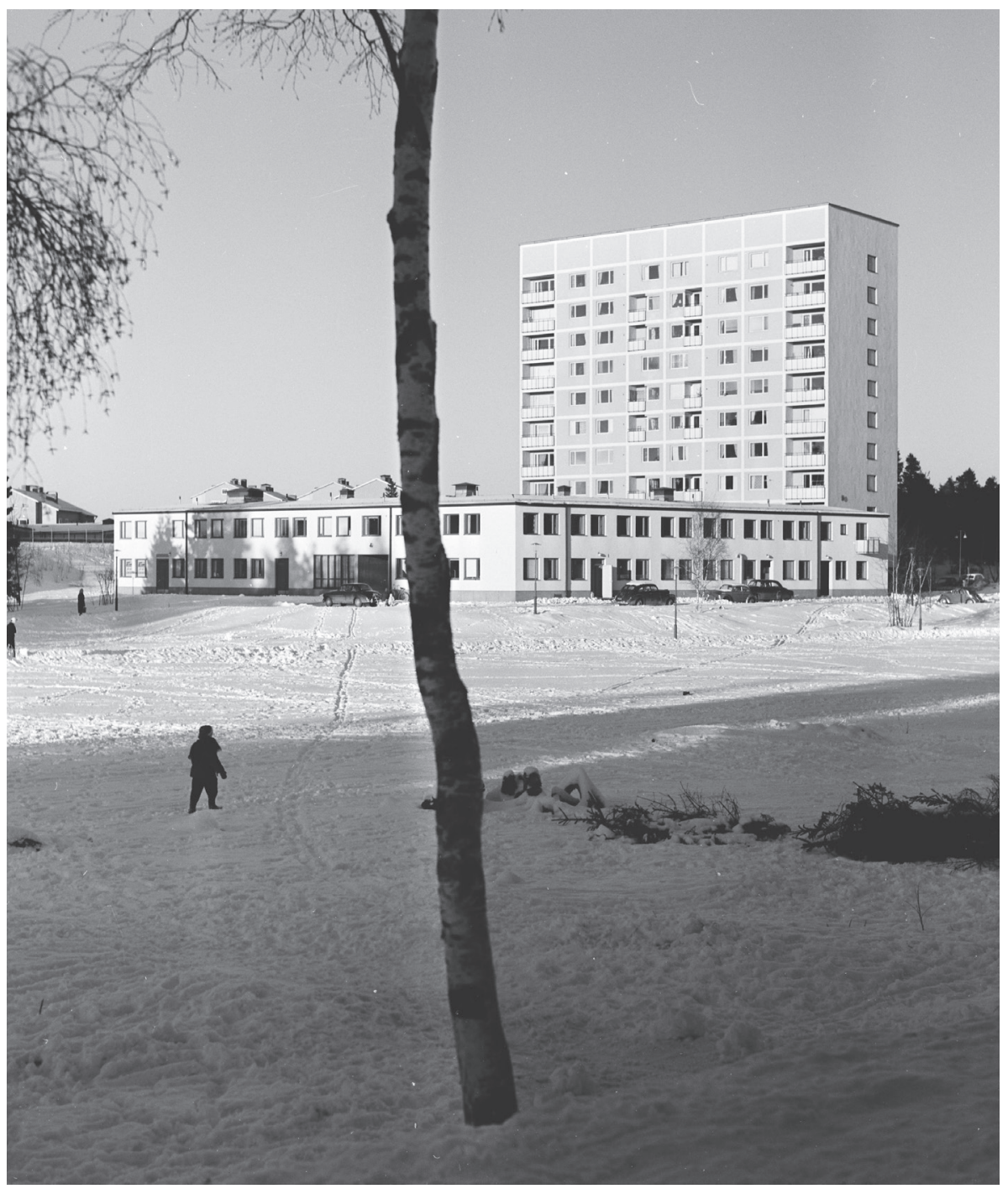

Figure 1. Stockholm suburb Bandhagen designed by Fred Forbat, Bengt Karlsson and Curt Strehlenert. Photo: Sune Sundahl, 1956. ArkDes collections. the avant-garde movements on the European continent and their connections with the Bauhaus. The 2019 anniversary series not only confirmed that such linkages were plentiful, and longstanding and that affinities and relationships were manifest between individuals as well as among professional networks and organizations, but they also presented examples of how archives can show, sometimes with high precision, how ideas, people, and objects migrate.

In the first presentation, Roger Jönsson pointed out how Forbat's memoirs in ArkDes' collections tell of an émigré architect's recollections from the meeting between experiences gained in and around the Bauhaus and his new homeland. ${ }^{9}$ Their contents can bring unique aspects to the history of Swedish architecture in the post-war years. In the second talk, Kerstin Wickman's fine-grained review of documents of architect Sven Markelius' (1889-1972) - one of the main protagonists of modern architecture in Sweden - archive showed how new data can add to the margins of already charted historical territory. Carefully preserved travel reports, photos, and itineraries disclose how Markelius, traveling on a grant in 1928 to visit air- 
ports, seems to have spent more time studying Bauhaus housing projects. With equal attention to archival details, Atli Seelow described in the third talk that by judging from dedications in books, the Swedish art historian and advocate of design reforms Gregor Paulsson (1889-1977) stayed in close contact with colleagues in Germany also well after the Second World War. ${ }^{10}$

Looking at the Bauhaus and Scandinavia, it is a crucial and intriguing historical circumstance when a broader introduction of modernism in Scandinavia coincided with the Bauhaus' difficulties maintaining operations around 1930 and its eventual closure in 1933. When the radical avant-garde came to a halt on the continent, it gained speed in Sweden. This temporal disjuncture opens speculations on what could have happened in art, design, and architecture if the Bauhaus hadn't been forced to close, and teachers and staff hadn't been dispersed around the world or tragically lost their lives in the war. In view of the continuation of modern Swedish architecture, it stands almost as an alternative history, testing whether the radicality of the Weimar Republic could be sustained under different political circumstances. Af- ter all, in Sweden, a fully-fledged modernist program was eventually implemented in a reformed political environment that catered to non-revolutionary socialism, as opposed to the often politically radical spirit of the continental movements. ${ }^{11}$

The example of the Bauhaus challenges the established histories of the modern movement, which were often written from national perspectives. The school's profound influence that diffused internationally makes it more appropriate to speak about transnational phenomena and modern movements in the plural rather than coherent national developments. However, this would make comparisons between different nations or regions such as Scandinavia even more relevant. And admittedly more complex. As it were, the Scandinavian "periphery" demonstrates sensitive and differentiated notions of adaptation and resistance towards the alleged "center".

\section{Forbat - Architect in Four Countries}

One of these fascinating transfers, bringing a radical-minded architect from the centre of the Bauhaus to flourish in a politically more moderate European periphery, is manifest in the career of the Hungarian-born Fred Forbat. Roger Jönsson, who has researched Forbat's architectural oeuvre between the wars, ${ }^{12}$ pointed out that the architecture training at the Bauhaus never reached the scale of urban planning. However, Forbat was drawn to city planning and that brought him to Munich to study for Theodor Fischer. Searching for new and progressive architecture, he moved from there to work for Walter Gropius in Weimar. Later, he was hired as a professor in city planning at Johannes Itten's art school in Berlin for a short period and declined a position as professor at the Bauhaus offered to him by Gropius' successor Hannes Meyer (according to Jönsson, probably because Forbat feared difficulties working with the increasingly radical Meyer). An offer to go to the Soviet Union on the Ernst May brigade to plan linear cities must have appeared "irresistible" for the progressively minded Forbat. However, the negative consequences of a top-down and consistently implemented large-scale planning doctrine soon proved disappointing to him. ${ }^{13}$ The transfer to Sweden in 1938 was aided by the international network of Swedish architects, Uno Åhrén among them, and Forbat's previous expe- 
riences would combine in a long career as an architect and town planner. According to Jönsson, Forbat strongly contributed to shaping the new profession of the urban planner in Sweden. From his first official assignment, the general plan for Lund in southern Sweden - a town that shared many similarities with his native Pécs - which was assigned to him by former Bauhaus student Sune Lindström ${ }^{14}$, to numerous plans for communities around the country. The Swedish colleagues were particularly curious about Forbat's experience from the Soviet Union. Forbat had much to contribute concerning the projective and prognosis methods developed for comprehensive planning. His general plan for the city of Skövde came to set the standard for planning mid-size cities, Jönsson argues, much due to the way Forbat employed scientific methods.

Forbat remained an essential link between foreign and Swedish architects as secretary to the Swedish CIAM group. Modernist at heart, an interim period of practice in Hungary in the early 1930s nevertheless indicated an interesting alternative strand, according to Jönsson. Compared to his radical designs in the early 1920s, a series of small houses for mainly Jewish commissioners - receiving commissions and practicing as a Jewish architect in Central Europe had become increasingly difficult by this time - shows a situated architecture rich in local influences. Even though these projects remained exceptions in Forbat's oeuvre, they, Jönsson speculated, could have developed into an exciting practice that indicated a possible turn also in Bauhaus' approaches and would have resonated well with several contemporary architects in Sweden. ${ }^{15}$ Still, as Forbat recognized the need for specialization in modern architecture, planning remained his focus in Sweden. However, the memoirs reveal that this was somewhat to his regret as Forbat describes how his carefully designed city plans sometimes came to be occupied by poorly designed houses. The ArkDes talk ended with a lively discussion among audience members about the Stockholm district Reimersholme.

\section{Design Education Reformed}

The establishment in 1945 of Konstfack, the independent university of Arts, Crafts, and Design was an influential institutional adaptation of the Bauhaus in Sweden. In the second talk, centered on crafts and design, Kerstin Wickman spoke about the national redesign of higher education in arts and crafts and how it was investigated for decades. ${ }^{16}$ While still integrated with the socalled Tekniska skolan, the pedagogy and understanding of the arts became increasingly outdated. Wickman noted somewhat sardonically that some students managed to get themselves appropriate training despite their education at the existing school, such as furniture designer and architect Greta Grossman, and textile designer Astrid Sampe who both successfully adopted ideas of modern design.

Representing the progressive Svenska Slöjdföreningen, art historian Gregor Paulsson was one of the harshest critics of the existing organization of design education. Paulsson owed his idea to reform architecture through craft partly to his education in Germany and his sympathies for the principles of the Deutscher Werkbund. The Werkbund's ambition to break up existing hierarchies between the arts and crafts and rethink the creative transfer between art and industry was carried on to the Bauhaus even if not entirely followed through - and 
was subsequently also integrated into the pedagogy of Konstfack. At the start, every department was headed by both an artistic director and a more technically oriented professional, a master craftsperson. In her talk, Wickman emphasized the Bauhaus' technical advancements- highlighting particularly the artistically and financially successful textile workshop as an extraordinarily advanced department - which helped disseminate the school's ideas throughout Europe. Students at the Bauhaus were encouraged to travel and learn from other schools and industries. ${ }^{17}$ This is how, for instance, Bauhaus textile designer Otti Berger spent time in Sweden as a pupil of Johanna Brunsson's weaving school in Stockholm. Even if Berger, according to Wickman's archival findings, seemed less interested in the aesthetic orientation of the workshop, it was a well-reputed school in Europe that attracted many international students. ${ }^{18}$ Students of the Bauhaus were also supposed to promote their school's ideals, and extant correspondence tells how Hannes Meyer encouraged Berger to lecture and inform about the Bauhaus in Sweden. In 1929 she became instrumental in introducing Bauhaus textiles (her own among others) at the Galleria Modern in Stockholm, an avant-garde gallery that staged a series of exhibitions in the late 1920s that would pave the way - and the critique - for the Stockholm Exhibition in 1930. Berger's stay resulted in a report back to the Bauhaus on Swedish weaving techniques and articles in Svenska Slöjdföreningens tidskrift (now Form) and the culturally radical Spektrum. ${ }^{19}$ According to Wickman, these writings demonstrate Berger's creativity and technical skills in textiles, which included both a new sense of space and new ideas about hygiene and functionality.

\section{A Swedish Manifesto?}

Such cultural transfers and relays proved central also to the third and concluding talk, focused on Acceptera, the Swedish functionalist manifesto published in 1931. Sven-Olov Wallenstein recalled that it was the "dela" of modernism to Sweden that first turned his attention to the publication. More specifically, it was Italian architectural historian Manfredo Tafuri's claim that the Siemensstadt housing project had proved that it was impossible for architecture to both maintain autonomy as an art form, and answer to the capitalist real- ity of production at the same time. After that moment, modernism could only exist as a form of "self-deception, an ideology or a mirage," Wallenstein argued, referencing Tafuri. ${ }^{20}$ Yet, the politically and financially backed implementation of modern architecture and design in Sweden contradicts Tafuri to some extent. It is this notion of ideology and power, and architecture becoming one agent among many in an assemblage that fascinates Wallenstein as a philosopher. Swedish modernism is distinguished by a more flexible way of thinking about modernization, a certain pragmatism. It could be explicated with Michel Foucault's notion of biopolitics, Wallenstein argued: a power structure that taps into life not by external disciplinary measures but by creating a surplus-value, thus shaping the individual subject inward-out and not topdown. Similarly, the originality of Acceptera consists of asking the reader to identify with modernity based on a new assemblage of freedom and the individual.

Helena Kåberg's and Atli Magnus Seelow's work with translations of Acceptera to English and German was also sparked by the relationship between the Swedish modern movement and the continental radical 


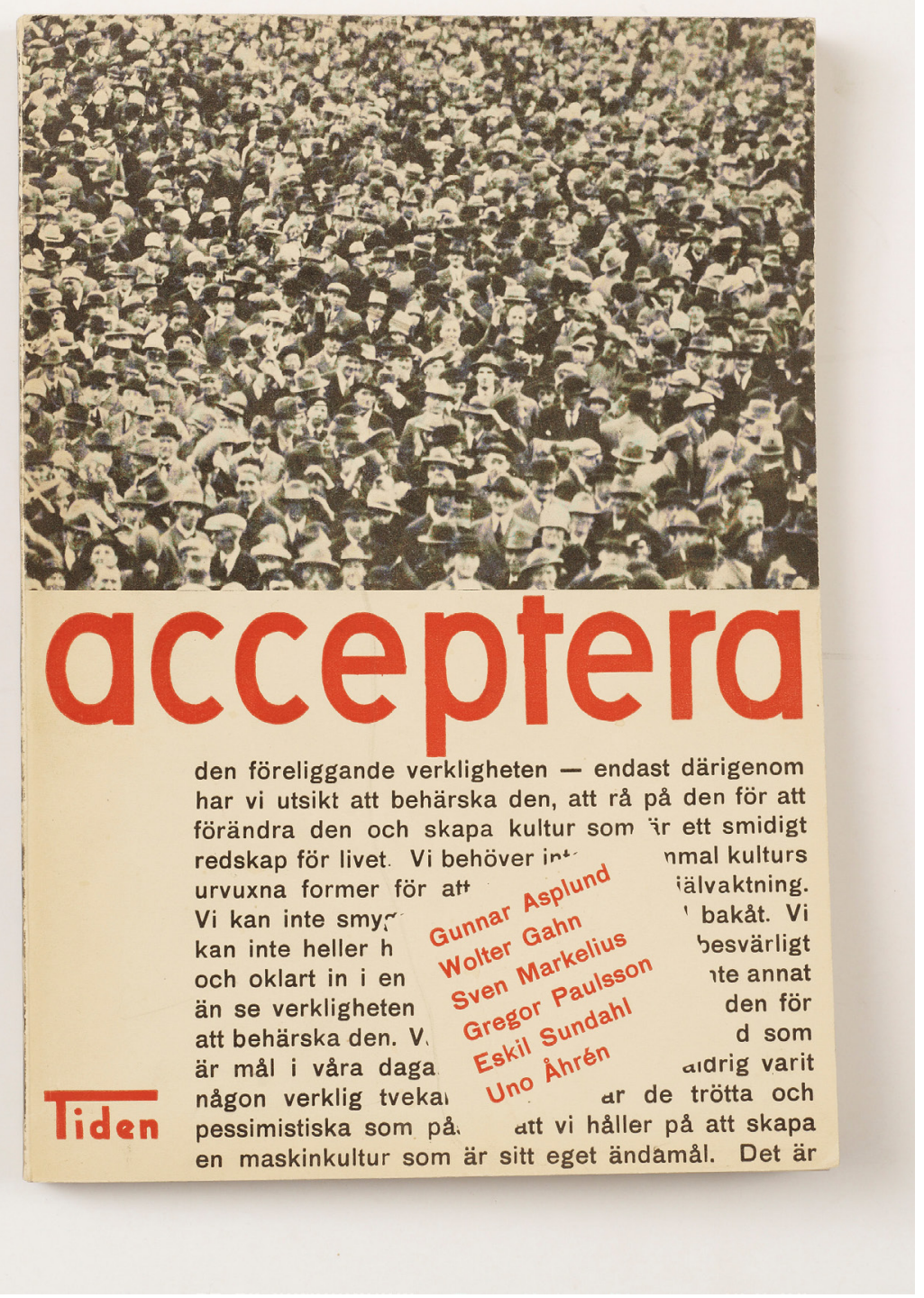

Figure 2. The cover of Acceptera (1931). avant-gardes. ${ }^{21}$ Kåberg, while teaching in the US, experienced a lack of original source material translated to English. The publications available at the time would fall short in introducing international students to the nuances and genealogies of thought and the actors beyond the heroic narratives of Swedish design. Seelow became aware of the importance of the Stockholm exhibition and Acceptera in disseminating modernism to the rest of Scandinavia while researching Icelandic modernism. And, in turn, he noted how heavily the publication relied on contemporary propaganda texts or manifestoes published on the European continent, especially in Germany. ${ }^{22}$ The authors of Acceptera borrowed images, even entire paragraphs, from magazines like Das Neue Frankfurt, the Bauhaus journal ${ }^{23}$ or books like Schönheit der Technik by Franz Kollmann, a popular edition in Germany at the time but lesser known in Sweden. ${ }^{24}$ This transfer 'from the continent to the north'25 fascinated Seelow and spurred his translation of Acceptera. However, the transfer is neither straightforward nor passively received. Notably, the authors of Acceptera could not claim a revolutionary spirit similar to many of the Euro- 
pean publications, thus much of their book revolves around creating a superstructure to support their argument. ${ }^{26}$ But such pragmatism united many contemporary architects on the continent, too. Archival research and close readings of texts tell of a more adaptable spirit less prone to overthrow existing power structures than the rhetoric would suggest. Le Corbusier's famous Architecture ou révolution ${ }^{27}$ intended to present architecture as a way of avoiding revolution, not an argument for revolution, Wallenstein reminded us.

Modern architects found different ways of signalling modernity, not the least by integrating other arts and media with architecture. This expansion of architectural discourse to photography, advertising, and moving images became integral to edifying a new architecture. ${ }^{28}$ Kåberg characterized Acceptera's novel layout as an all-immersive experience where image and text are insoluble. It offered a new way of reading, almost cinematic, that followed the New Typography Movement; it is visual media as much as text. The language, too, was saturated by such experiments, Wallenstein added. To create a young, cheeky, and eager effect similar to the Bauhaus practice to abandon the capitalization of nouns in German, the Swedish authors of Acceptera dropped the traditional plural forms of verbs. ${ }^{29}$

The panel's conversation made clear that the continental sources, ideas, or aesthetics of Acceptera were not imported one to one. Instead, the Swedish protagonists co-created a variety of artistic and political collages for the new context. They varied from typographic and graphic innovations such as the sans serif typeface to more wide-ranging ideological claims. For example, the authors aligned with Gustaf Näsström's building typology analyses demonstrating that Swedish vernacular architecture was inherently modern. ${ }^{30}$ And to further enhance the rationality of domestic building traditions, the key protagonists established the word "funktionalism" for their architecture in Swedish, rather than using another German, but more aesthetically charged concept, the Neues Bauen. ${ }^{31}$

\section{The Power of Archives}

The profound influence that institutions collecting and exhibiting exert on historiography became evident even in this small program series. For instance, Helena Mattsson's and Wallenstein's book 1930/31 Swedish Modernism at the Crossroads (2008) was commissioned by the Documenta exhibition in Kassel with an ambition to map multiple modernities. The same year, the MoMA published the commented translations of Three Founding Texts (including Acceptera) co-edited by Helena Kåberg. The founding of the Bauhaus-Archiv in 1961 can not be underestimated. For the Swedish context, the Archiv's early contacts with Forbat are significant. They would lead not only to an international traveling exhibition (introducing Forbat also to Swedish audiences ${ }^{32}$ ) but also encouraged him to collect and author his memoirs. Their 2019 publication by the Bauhaus Archiv, eventually made a "Bauhäusler's" recollections travel from oblivion in an ArkDes archive into the Bauhaus canon.

While the Swedish Nationalmuseum was relatively late with including modern furniture and objects from the Stockholm Exhibition in their collections, today, the idea of merging the arts - brought to Sweden from the Deutscher Werkbund and the Bauhaus by Gregor Paulsson among others - is guiding the museum's new permanent exhibition. Helena Kåberg, the responsible curator of 


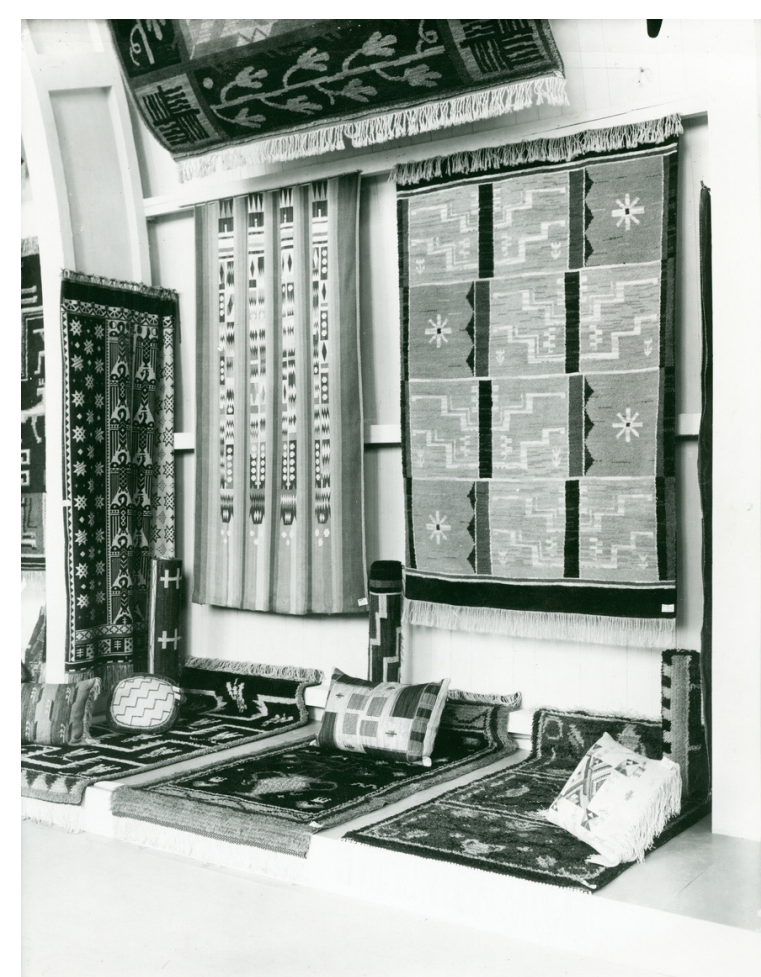

Figure 3. Textiles of Johanna Brunsson's weaving school presented at the Stockholm Exhibition 1930. Photo: Vänersborgs museum. the display, anecdotally revealed how she hung the portraits of Paulsson and Herman Bergman, an art caster and the founder of an influential foundry, next to each other in the museum's restaurant. Even if the two gentlemen disagreed on arts and crafts in their lifetime, their debate could continue in spirit by juxtaposing within the museum's walls.

Inadvertently, "Bauhaus in the Archive" at ArkDes became a call for further research. The series pointed to the fundamental importance of the artistic movements on the continent for the theory and practice of modern architecture and design in Sweden, and how much more is to be done. The transfer of ideas from the Bauhaus to Sweden occurred during an extended period and involved more individuals than typically acknowledged in the abbreviated canon narratives. The archive also bears witness to difficult histories seldom communicated. Jönsson pointed out that in Forbat's case, even though he was successfully integrated into a new country, the archive reveals outright confrontation with colleagues because of his non-Swedish origin. And his files kept at the Swedish intelligence service can further detail the hardship facing an architect in times of war. Wickman's research makes evident that there is more to dig out about the education and networks of female designers in Sweden who practiced before equal possibilities to professional training were available. ${ }^{33}$ And Seelow described how he keeps stumbling across printed matter that later re-surfaced in Acceptera, tying it still closer to the continent and its contested histories. With the help of the archive, the individual actors, events, and instances can be gathered to form a fuller picture. Or, as Kerstin Wickman pointed out in her presentation, "the archive can show us how ideas become manifest."

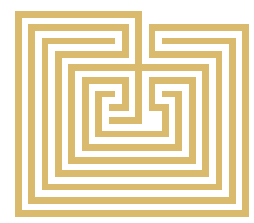




\section{Endnotes}

1 The series was initiated by the author, at the time research coordinator at ArkDes, and organized in collaboration with ArkDes library and collections through head librarian Lena Biörnstad Wranne and curator of collections Frida Melin. For the content of this article, I am indebted to the information provided by the guests of the series. Unless otherwise stated I am referencing information voiced during public talks on September 10 (Roger Jönsson), October 1 (Kerstin Wickman), and November 5 (Helena Kåberg Atli Magnus Seelow and Sven-Olov Wallenstein). 2 Roger Jönsson is an architect and gained his PhD through the Faculty of Engineering (LTH), Lund University for a doctoral dissertation on Fred Forbat in 2004.

3 Kerstin Wickman is former Professor at Konstfack, design critic and author.

$4 \quad$ Prof. Dr. -Ing. Atli Magnus Seelow is currently based at the Friedrich-Alexander University in Erlangen-Nuremberg. 2015-2019 he was associate professor of history and theory of architecture at Chalmers university of Technology in Gothenburg. $5 \quad$ Helena Kåberg, $\mathrm{PhD}$, is an art historian and senior curator at Nationalmuseum, Stockholm. 6 Sven-Olov Wallenstein is Professor of Philosophy at Södertörn University.

7 Asplund, Gunnar, Åhrén, Uno, Gahn, Wolter, Markelius, Sven, Paulsson, Gregor \& Sundahl, Eskil, Akzeptiere: das Buch und seine Geschichte. Translation to German with introduction and comments by Atli Magnus Seelow, (Erlangen: FAU University Press, 2018).

8 Cultural anthropologist Aleida Assman explores cultural memory and the realtionship between canon and archive in Aleida Assman, "Canon and Archive", in a Companion to Cultural Memory Studies, eds. Astrid Erll and Ansgar Nünning (Berlin: de Gruyter, 2010)

9 Forbats memoirs, written in German, were published in the "Bauhäusler" series by Bauhaus Archiv in 2019. Forbat, Fred, Erinnerungen eines Architekten aus vier Ländern, (Berlin: Bauhaus-Archiv, 2019). The memoirs of Werner Taesler who studied at the Bauhaus and came to settle in Sweden were also published in 2019. Taesler, Werner, Flüchtling in drei Ländern: ein Bauhaus-Architekt und Sozialist in Deutschland, der Sowjetunion und Schweden: kommentierte Edition seiner Aufzeichnungen,

(Stuttgart: Edition Amici im Verlag opus magnum, 2019).

10 Atli Seelow mentioned among others the former Professor at TU Munich, Johannes Ludwig who had strong ties with Sweden.

11 This topic was elaborated especially by Seelow and Wallenstein in the third talk of the series. 12 Jönsson, Roger (2004). Arkitekt $i$ mellankrigstidens Europa: Fred Forbat och funktionalismen. (Lund: Lund University, 2004), doctoral dissertation

13 Ibid., 279ff

14 At the time of the plan (1939-1942) Lindström had just set up his office and lacked time to fully engage in the assignment. Although co-authored with Lindström, Jönsson argues the plan was mainly conceived by Forbat. Jönsson 2004, p. 397ff. 15 Jönsson states that Forbat became an undogmatic 'outsider' among the Hungarian CIAM members. Jönsson 2004 p. 392.

16 See also Kerstin Wickman's article in this publication.

$17 \quad$ For further orientation on Bauhaus weaving theory and the writings of weavers active at the Bauhaus, see Smith, T'ai, Bauhaus Weaving Theory. From Feminine Craft to Mode of Design (Minneapolis: University of Minnesota Press, 2014).

18 Rosell-Åström, Kristina (red.), Johanna Brunsson: pionjär inom svensk vävkonst (Göteborg: Gustaf Werner AB, 1982).

For more on the history of Konstfack, see Beckman, Ulf, Tanken och handen: Konstfack 150 år.
(Stockholm: Page One, 1994); Helgeson, Susanne (red.), 175 år av kamp, glädje och misslyckanden, (Hägersten: Konstfack, 2019).

19 Kerstin Wickman, "Impulserna kom från Tyskland", https://www.goethe.de/ins/se/sv/kul/sup/ bhs/21697875.html, accessed 2020-07-30. See also Widar Halén's studies on Berger and the Nordic countries at https://www.nasjonalmuseet.no/en/ stories/explore-the-collection/otti-berger-og-nordeneng/, accessed 2021-09-05.

20 See also Helena Mattsson and SvenOlov Wallenstein, 1930/31 Swedish Modernism at the Crossroads, (Stockholm: Axl Books, 2009), 34f, and Manfredo Tafuri, Progetto e utopia (Bari: Laterza, 1973). Trans. by Barbara Luigi la Penta as Architecture and Utopia (Cambridge, Mass.: MIT Press, 1976).

21 Creagh, Lucy, Kåberg, Helena \& Lane, Barbara Miller (eds.), Modern Swedish Design: Three Founding Texts, (New York: Museum of Modern Art, 2008).

22 Seelow mentioned particularly Gropius International architecture, Walter Behrendt's The Victory of the New Building Style and Adolf Behne's The Modern Functionalist Building, alongside Le Corbusier's books.

23 For commented facsimile editions of the Bauhaus journal, see Bähr, Astrid \& Müller Lars, Bauhaus journal 1926-1931: facsimile edition. (Zürich: Lars Müller Publishers, 2019).

24 The connection was not discovered by

Seelow until after the 2018 translation was published and does not appear in the annotations.

$25 \quad$ Atli Magnus Seelow, "From the Continent to the North - German Influence on Modern Architecture in Sweden", Konsthistorisk tidskrift/Journal of Art History, vol. 85:1 (2016): 44-62.

26 See Seelow's introduction to the translation of Acceptera.

$27 \quad$ Intended as the original title of Vers une Architecture, "Architecture ou révolution" was kept as

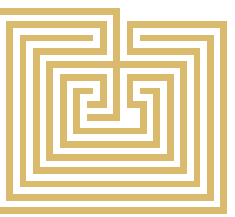


the heading of the books final and most well-known chapter. See for example Brott, Simone, "Architecture et Révolution: Le Corbusier and the Fascist Revolution", Thresholds 41 (Spring 2013).

28 Architecture theorist Beatriz Colomina has published extensively on this matter, most notably

Privacy and Publicity: Modern Architecture as Mass Media, (Cambridge, Mass.: MIT Press, 1994).

29 In the beginning of the 1930s the

singular forms were still considered experimental

in published text. Fiction writers would increasingly adopt the singular throughout the 1930s, media in the early 1940s, and in 1967 the plural forms were

eventually banned from legal texts too. Gertrud

Pettersson, Svenska språket under 700 år. (Lund: Studentlitteratur, 1996) 162.

30 Gustaf Näsström.

$31 \quad$ Eva Rudberg.

32 The exhibition that opened in Darmstadt

1969 was shown in Stockholm 1970. Fred Forbat:

arkitektur och stadsplanering i Tyskland, USSR,

Ungern och Sverige 1919-1969, Stockholm: Sveriges arkitekturmuseum, 1970.

33 In a related field, Catharina Nolin's research on Swedish female landscape architects shows

extensive international connections. Catharina Nolin, "Networking and Collaborating: Notes on Swedish

Women Landscape Architects 1935-1970", in Mikael

Andersson and Christina Pech (eds.), ArkDes

Research Symposium on Architectural History 2018

(Stockholm: ArkDes, 2020).
Christina Pech is an architectural historian

teaching and researching at KTH Royal In-

stitute of Technology. Between 2015 and

2019 she worked at the Swedish centre

for architecture and design, ArkDes, as a

researcher and research coordinator.

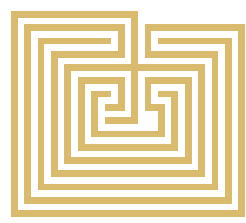

